\title{
Vuorovaikutuksen tutkimus - tiedettä tiedon ja hyödyn vuoksi
}

Viimeaikaisessa tiedepoliittisessa keskustelussa on perustutkimuksen merkitys ollut korostuneesti esillä. Monet ovat ottaneet kantaa perustutkimuksen puolesta. Perustutkimuksellahan tarkoitetaan tutkimusta, joka ei tähtää sovelluksen, tuotteen tai minkään erityisen kehityksenkään aikaansaamiseen. Sen pontimena on tutkijan idea siitä, että emme vielä tiedä, miten asia on. Tutkija haluaa etsiä ja tuottaa uutta tietoa. Tämän vuoksi perustutkimuksesta käytetään myös nimitystä uteliaisuustutkimus. Perustutkimusta siivittää tiedonhalu ilman että näköpiirissä olisi tulosten taloudellista tai muutakaan hyödynnettävyyttä.

Soveltava tutkimus taas tähtää perustutkimuksessa tuotetun tieteellisen tiedon soveltamiseen niin, että käytännön elämämme jotenkin siitä hyötyy. Soveltava tutkimus nojaa perustutkimuksen saavutuksiin. Yleisesti tunnustetaankin perustutkimuksen vahva merkitys tieteen perustana. Kuitenkin kahtiajako perustutkimuksen ja soveltavan tutkimuksen kesken on liian karkea, eikä vastakkainasettelua pidä suosia.

Akateeminen tutkimus perustutkimuksen synonyymina on korostanut sitä, että nimenomaan yliopistot ovat perustutkimuksen tyyssijoja. Tämä ei taida enää pitää paikkaansa, sillä yliopistotkin tähtäävät nykyään tutkimustulostensa kaupalliseen hyödyntämiseen. Ja toisaalta myös yritysmaailmassa tehdään varsinkin instrumentaalista ja kokeellista perustutkimusta, jonka hyödyt eivät ole välittömästi tiedossa.

Nykyään puhutaan myös innovaatiotutkimuksesta tai innovaatiohakuisesta tutkimuksesta. Innovaatiot ovat keksintöjä, sovelluksia tai tuotteita, joilla on uutuusarvoa ja jotka koetaan yhteisössä tai yhteiskunnassa tärkeiksi. Perustutkimuksessa on karttunut tietoa tai osaamista, jonka innovoija hyödyntää uudella tavalla tai uudessa ympäristössä. Innovaatio tuottaa usein myös taloudellista hyötyä. Toki innovaatioita ovat myös sosiaaliset ja kulttuuriset "keksinnöt", jotka yhteisö ottaa käyttöön. Ja ilman muuta innovaatiot voivat olla myös viestinnällisiä ja vuorovaikutuksellisia uutuuksia.

Miten perustutkimus ja soveltava tutkimus näyttäytyvät suomalaisessa puheviestinnän tutkimuksessa? Ihmisten keskinäinen vuorovaikutus on rikas kohde kaikenlaiselle tutkimukselle. Perustutkimus ammentaa runsaasti tutkittavaa vuorovaikutussuhteista, ryhmäviestinnästä tai teknologiavälitteisestä kanssakäymisestä. Tutkimustyön pontimena ei ole se, että tuloksia aiottaisiin hyödyntää käytännössä. Ihminen on kiinnostunut itsestään. Kaikki tieto ihmisestä ja ihmisten viestinnästä on meille tärkeää ja sellaisenaan itseisarvo. 
Toisaalta sovellukset tulevat vuorovaikutustutkijan luokse aivan kutsumatta. Mikä tahansa ihmisten vuorovaikutuskäyttäytymistä koskeva tieto voi olla avuksi esimerkiksi vaikuttavuuden tai osaamisen näkökulmasta tarkasteluina. Uutta tutkittua tietoa tarvitaan kaikissa viestintäkonteksteissa vaikkapa interpersonaalisen vuorovaikutuksen kehittämisessä, yhteisöllisyyden parantamisessa tai tiedonkulun vahvistamisessa. Viestinnän tutkimuksen tulosten sovellettavuusarvo on aina suuri.

Mitkä olisivat sellaisia innovaatioita, joihin nykyinen vuorovaikutustutkimus voisi tähdätä ja joiden kehittäminen perustuisi vankalle perustutkimukselle? Olisiko tiimin sisäisen vuorovaikutuksen ja tiimityön tuloksellisuuden keskinäisiä sidoksia kuvaava malli innovaatio? Tai persoonallisuuspiirteiden ja vuorovaikutusosaamisen välistä yhteyttä ennustava testi?

Vuorovaikutuksen tutkijoilla tulisi olla malttia paneutua myös sellaisiin tutkimusaiheisiin ja -kohteisiin, jotka edistävät puheviestinnän teorianmuodostusta. Suomalaisessa tutkimuksessakin pitäisi yhä useammin uskaltautua myös teoreettisiin kysymyksiin, siis tähänastisen teoriaperustan koettelemiseen ja kehittämiseen. Vähimmillään tämä tarkoittaa sitä, että tutkimuksen teoreettinen viitekehys on vankka ja että siihen sisällytetään uusin tieto. Seuraava askel on se, että empiirisen aineiston analyysin pohjalta palataan omaan teoreettiseen viitekehykseen ja että sitä tutkiskellaan omien havaintojen tuottaman tiedon avulla. Askel vieläkin pitemmälle olisi se, että rohkenisimme esittää teoreettisia johtopäätöksiä empiirisen tutkimusprosessin pohjalta.

Meidän tulisi Suomessa reippaammin myös kyseenalaistaa tähänastista tietoa ja arvioida julkaistua tutkimusta. Systemaattisesti laaditut analyysit tutkimuskirjallisuudesta ovat tässä hyvä väline. Myös tutkimusmenetelmien lähitarkastelua, vertailua ja evaluointia kaivataan.

Perustutkimuksen ja soveltavan tutkimuksen väliset linjanvedot ovat näkyvissä myös tässä uudessa Prologissa. Prologin eli puheviestinnän vuosikirjan missiona on esitellä tuoreinta Suomessa tehtyä tutkimusta suomen kielellä. Tämä on seitsemäs Prologi. Suomalaisen vuorovaikutustutkimuksen tilasta kertoo se, että vuosikirjaan hyväksytyt referee-artikkelit ovat valikoituneet jo varsin tiheän seulan lävitse. Laatu on siten kohdallaan.

Toimituskunta on käyttänyt harkintavaltaansa julkaisuprosessin kaikissa vaiheissa. Toimituskunnalle tarjottiin viisitoista abstraktia artikkeliehdotuksiksi. Näistä hyväksyimme jatkotyöstettäviksi kymmenen. Näiden pohjalta toimituskunta sai seitsemän artikkelikäsikirjoitusta, joista toimituskunta päätti lähettää referee-arvioijille kuusi. Vertaisarvioijat antoivat myönteisen signaalin viidelle artikkelikäsikirjoitukselle, joskin kaikista käsikirjoituksista löytyi parannettavaa. Toimituskunta oli arvioijien kanssa samaa mieltä ja edellytti, että lausunnossa annetut parannusehdotukset otetaan huomioon käsikirjoituksen työstämisessä. Lopputuloksena on kolme referee-arvioinnin läpikäynyttä 
artikkelia, jotka hyvillä mielin julkaisemme tässä teoksessa. Lisäksi meillä oli ilo saada mukaan yksi tutkimusseloste, yksi puheenvuoro ja yksi lectio praecursoria.

Prologi on varteenotettava julkaisukanava. Tästä kertoo se, että Tieteellisten seurain valtuuskunnan perustama Julkaisufoorumi on ottanut Prologin mukaan luetteloonsa (ks. www.tsv.fi/julkaisufoorumi). Julkaisufoorumin tarkoituksena on arvioida ja järjestää sekä kansainvälisiä että kotimaisia julkaisuja laadullisin perustein. Foorumi kattaa parikymmentä tuhatta lehteä ja sarjaa. Julkaisufoorumiin siis kootaan ne tieteelliset julkaisut, joihin kannattaa tarjota artikkelinsa tai muun kirjoituksensa.

Nyt onkin aika levittää tietoa Prologista hyvänä julkaisukanavana laajemminkin eli kaikille niille tieteenaloille, joissa tutkitaan ihmisten välistä vuorovaikutusta. Kirjoittamiskutsumme vuoden 2012 Prologia varten heijastaa tieteidenvälisyyden ideologiaa. Meidän kannattaa hakeutua läheisempään vuoropuheluun muiden alojen tutkijoiden kanssa.

Esitän parhaat kiitokseni kirjoittajille hyvästä yhteistyöstä sekä vertaisarvioijille pyyteettömästä toiminnasta Prologin hyväksi. Lämpimät kiitokset myös toimituskunnan jäsenille Anu Sivuselle ja Vilja Laaksoselle mukavasta ja tehokkaasta tiimityöstä. Erityiskiitos kuuluu toimitussihteerille Vilja Laaksoselle, jonka aloitteellisuus, tarkkuus ja ripeys siivittivät koko vuoden työskentelyä.

Jyväskylässä marraskuussa 2011

Maarit Valo, päätoimittaja 